\title{
Unemployment experiences in context: A phenomenological study in two townships in South Africa
}

\author{
Melinda du Toit, Hans De Witte, Sebastiaan Rothmann \& Anja Van den \\ Broeck
}

To cite this article: Melinda du Toit, Hans De Witte, Sebastiaan Rothmann \& Anja Van den Broeck (2018) Unemployment experiences in context: A phenomenological study in two townships in South Africa, Journal of Psychology in Africa, 28:2, 122-127, DOI: 10.1080/14330237.2018.1454575

To link to this article: https://doi.org/10.1080/14330237.2018.1454575

曲 Published online: 14 May 2018.

Submit your article to this journal $₫$

Џ Article views: 17

Q View related articles $₫$

View Crossmark data $\asymp$ 


\title{
Unemployment experiences in context: A phenomenological study in two townships in South Africa
}

\author{
Melinda du Toit ${ }^{1,2, *}$, Hans De Witte ${ }^{1,2}$, Sebastiaan Rothmann ${ }^{1}$ and Anja Van den Broeck ${ }^{1,3}$ \\ ${ }^{1}$ Optentia Research Focus Area, North-West University, Vanderbijlpark, South Africa \\ ${ }^{2}$ Research Group Work, Organisational \& Personnel Psychology, KU Leuven, Leuven, Belgium \\ ${ }^{3}$ Research Centre for Work and Organisation Studies, KU Leuven, Brussels, Belgium \\ *Corresponding author email: Melinda.dutoit@nwu.ac.za
}

\begin{abstract}
This study aimed to explore the unemployment experience of residents of a historically disadvantaged South African neighbourhood. Informants were twelve black community members (females $=75 \%$; age ranges: 20 to $29=58.3 \%$, and 30 to $39=33.3 \%$ ). Individual interviews were conducted with the participants. Thematic analysis of the data revealed that participants valued employment despite their present unemployment. They indicated that being unemployed is a painful experience, but that they also held an optimistic view of a future in which they would have employment. The findings further suggest that diminished social support by the community and public social welfare agencies aggravate negative experiences of unemployment. Employment support programmes are needed to connect the unemployed to job networks; as well as to empower those who are unemployed to fulfil their positive work participation expectations.
\end{abstract}

Keywords: community incohesion, experience, political context, township, South Africa, unemployment

\section{Introduction}

Unemployment is both an individual status and a social status ascription (Aldrich \& Dickie, 2013; Fowler \& Etchegary, 2008; Mckenzie, 2013; Sage, 2017; Shattuck \& Roux, 2015; Sherman, 2013). For instance, Sage (2017) considered the consequences of unemployment for the individual to include psychological distress associated with a decline in life satisfaction; as well as risks for mood disorder and substance abuse. As a social status ascription, unemployment is associated with stigmatisation, labelling, unfair judgement, and marginalisation (Aldrich \& Dickie, 2013; Dawson 2014; Mckenzie, 2013 \& Sherman, 2013). To mitigate the personal and social consequences of unemployment, improvement of social support to the unemployed as well as policy level interventions, are equally important as individual-level interventions (Shattuck \& Roux, 2015).

Context matters to the meanings associated with unemployment; as well as the personal and social consequences thereof (e.g., Altbeker \& Bernstein, 2017; De Witte, Rothmann, \& Jackson, 2012; Leibbrandt, Finn, $\&$ Woolard, 2012). Most of the studies on unemployment experiences have been executed in developed countries with relatively few of the studies carried out in the emerging countries of Africa (Plattner \& Gonzo, 2010). This study aimed to explore the unemployment experiences of unemployed individuals from a typical South African township community; in order to provide preliminary data for use in developing an intervention programme for the unemployed within their township communities.

Unemployment is estimated at $60 \%$ among South Africa's historically disadvantaged communities (Mahajan, 2014). The national unemployment rate stands at $27.7 \%$ (36.8\% with the expanded definition). Most of the unemployed are members of the black population living in informal urban settlements. These settlements mushroomed in the past 20 years and are an after-effect of apartheid-era racial segregation creating an 'underclass' from 1958 to 1994 (Burger, Van der Berg, Van der Walt, \& Yu, 2017; Seekings, 2003). Of the almost 6.2 million unemployed in South Africa, 88.7\% are black (Statistics South Africa, 2017). As a result, almost $65 \%$ of black South Africans live below the poverty line (i.e. 992 ZAR / 76.28 USD per person per month in 2015) (Poverty Trends in South Africa, Statistics South Africa, 2017). Nonetheless, South Africa boasts of a vibrant informal job market (Fourie, 2011, 2012; Lloyd \& Leibbrandt, 2013, 2014). An estimated 1.5 million people operated a small informal business in 2013, 70\% of whom are unemployed and who use this as an effort to acquire an income (Informal business, a means of survival, Statistics South Africa, 2014).

Within the informal sector employment, we differentiate between informal wage employees and informal self-employed persons. According to Statistics South Africa, informal self-employed persons are predominantly black individuals aged between 35 and 44 years old with the lowest levels of education (Press statement: Survey of employers and the self-employed, Statistics South Africa, 2014). The informal self-employed industry comprises mostly of Spaza' shops (small general dealers), street vendors, car wash concerns, and hairdressers.

Most studies on employment appear to overly privilege formal sector employment, discounting the fact that billions of people from developing countries around the world are employed in the informal sector. Furthermore, South Africa - with its high unemployment rate and measured against similar countries - has a huge informal self-employed sector (Yu, 2012). Thus, we proposed this study, mindful of the prejudices that come with selfemployment or small business enterprise employment in the informal sector, as compared to employment participation in the formal sector. 
The question remains as to how residents from historically disadvantaged black communities experience their lack of formal employment. An in-depth exploration of the lived unemployment experiences in historically deprived black neighbourhoods would be most revealing.

\section{Goal of the study}

The current study aimed to explore the lived experiences of unemployed black people in a historically deprived South African community (also called a township). This study was guided by the following research question: What are the formal sector unemployment experiences of the residents of a South African black township?

\section{Method \\ Research design}

This study utilised a phronesis approach to exploring the unemployment experiences of residents of a historically marginalised black community. A phronetic research approach is a form of appreciative inquiry adopting a caring and respectful attitude to understand the issues of interest from the view of the participants (Flyvbjerg, 2010; Tracy, 2013). Thus, phronetic research was suited to our goal to arrive at a deep and nuanced understanding of the experiences of unemployment.

\section{Participants and setting}

Informants were a convenience sample of twelve black community residents of Boipatong and Orange Farm, Gauteng Province, South Africa (see Table 1 for participant demographics). These communities are marked by rundown basic infrastructure, poor service delivery, and lack of resources and investment. Our informants were between the ages of 18 and 64 at the time of study. Additionally, they self-reported to have been unemployed for six months or more. We recruited the participants utilising snowball sampling with signed-up participants helping to identify eligible others.

\section{Data gathering}

We utilised in-depth, semi-structured interviews to interview the informants about experiences of unemployment by people residing in township communities. Additionally, we asked participants to address their views on employment prospects in the future.
To ensure credibility and trustworthiness of the data, the first listed author maintained an extended personal presence in the community of study with informal observations of the residents' daily lives, feelings, and actions. Lastly, the researchers attempted to achieve transferability through an accurate description of the research process (see Kumar, 2014 for guidelines).

\section{Procedure}

Permission for the study was granted by the Human Health Research Ethics Committee (HHREC) at the North-West University, South Africa. The participants individually consented for participation in the study. Six trained field workers from sister communities, to those of the study, assisted with data collection. As a token of appreciation for their time, each participant received 80 ZAR in grocery gift cards that could be used at a local chain store. A psychological counsellor was requested to be on stand-by should such a need arise by the participant during or after the interview.

\section{Data analysis}

We analysed the data utilising ATLAS.ti 8 (Creswell \& Poth, 2017; Friese, 2014). We utilised an inductive open coding process guided by a code-document tabulation in order to determine the most verbalised experiences across the interviews. We ensured rigour of thematic analysis with co-coders consensus checks at every stage. From these verbalised experiences, the four central and overarching themes were determined. We used D letter identifier codes for a unique statement by our study participants.

\section{Results and discussion}

Four themes emerged which characterise the unemployment experiences of the black community residents: Unemployment as a painful experience; hope and optimism; living in a township community; and disconnected from political and economic forces. Elaboration on these themes and the evidence for them will subsequently be presented.

\section{Theme 1: Unemployment as a painful experience}

All participants desired formal employment and described unemployment using such negative terms as "a huge garbage heap filled with bad things" (D1); "life is over"

Table 1. Respondent ID, gender, age, place, length of unemployment and level of education

\begin{tabular}{|c|c|c|c|c|c|}
\hline Number & Gender & Age & Place & Years unemployed & Level of education \\
\hline D1 & Female & 24 & $\mathrm{OF}$ & 1 year & Grade 12 plus financial learnership \\
\hline D2 & Female & 38 & $\mathrm{OF}$ & 6 years & Grade 10 \\
\hline D3 & Male & 22 & $\mathrm{OF}$ & 4 years & Grade 12 \\
\hline D4 & Female & 31 & $\mathrm{OF}$ & 2 years & Grade 12 \\
\hline D5 & Male & 22 & $\mathrm{~B}$ & 1 year, 7 months & Diploma in Marketing \\
\hline D6 & Female & 32 & $\mathrm{OF}$ & 2 years, 6 months & Grade 10 \\
\hline D7 & Female & 29 & $\mathrm{~B}$ & 5 years & Grade 12 with N4 in Engineering \\
\hline D8 & Female & 25 & $\mathrm{OF}$ & 4 to 5 years & Grade 12 \\
\hline D9 & Female & 41 & $\mathrm{~B}$ & 6 years & Grade 11 \\
\hline D10 & Female & 38 & $\mathrm{~B}$ & Many years, on and off & Grade 12 \\
\hline D11 & Male & 20 & $\mathrm{~B}$ & 2 years & Grade 12 \\
\hline D12 & Female & 21 & $\mathrm{~B}$ & 2 years & Grade 12 plus certificate in Engineering \\
\hline
\end{tabular}


(D15); "danger and death" (D18); and "a man-made grave and a monster" (D19). D14 explained that unemployment brings "a black heart full of sorrow and pain; the heart is broken, angry, sore, and sad." The participants described their experience of life as difficult, sad, and painful (D1, D14, D15, D16, D17, D18, D19, D20, D21, D22, \& D23). Feelings of anger also surfaced in the depiction of unemployment (D14). Additionally, unemployment was associated with stress, depression, anxiety attacks, and suicide ideation (D1, D14, D16, D17, D19, \& D20). These feelings might lead to undesirable behaviours such as drug and alcohol abuse, crime, and suicide attempts (D1, D14, \& D17).

According to participant D14 "to be not working like this, it is bad, nothing to move you into action, you see, it demotivates a person." Moreover, the children and dependents of unemployed people suffer from their exposure to the 'ugly side' of life and as parents are unable to provide for their children due to a lifetime of suffering and disadvantages (D1, D15, \& D19). Their children suffer from basic needs deprivation and are ridiculed for their poverty (D14, D17, D18, D19, \& D20).

From these narratives it became clear that unemployment poses a tremendous challenge for all the respondents. It is an undesirable situation with which they have difficulty dealing. Long-term unemployment also produced the loss of personal agency: "We don't think. We have to be sheep. We are the followers ... They don't change, they... even if they are literate, they still think like black people" (D19); and reinforced racial stereotypes about blacks as 'lazy' or lacking initiative, drive, energy, and internal motivation (D1, D14, D15, D17, D18, D22, \& D23). However, the desire to avoid the "lazy label" was also a motivating factor: "Some of us who want to find jobs must stop being lazy, expecting everything to be done for us" (D15) and "that's the problem, you become lazy and dependent on the government to do everything for us" (D22). As was found by Sherman (2013) and Patrick (2014), the respondents reported the need to have a goal in life - a sense of purpose which they felt a job could provide.

The participants felt the pain of stigmatisation and shame because they are of the opinion that society perceives them as not honestly trying their best to find work. Mckenzie (2013), Patrick (2014), and Sherman (2013) also reported that unemployed people in low income, marginalised communities suffer from being judged by others and that they face stigmatisation, prejudice, and intolerance. Both a lack of direction and task-orientation as well as the sting of a perceived stigma associated with unemployment, bring additional pain and discomfort. Often this social labeling and social denouncement cause the unemployed people to internalise these stigmatising labels and ascribe to it themselves.

Each of the participants discussed a survivorship activity they engaged in to earn some money; which they termed "hustling". Typical "hustling" activities included washing cars (D14), doing neighbours' hair (D18), re-selling beauty products for commission (D15), or providing painting, cleaning or ironing services to neighbours or the residents of nearby towns (D14, D19,
\& D20). Sometimes these "hustling" activities involved illegal activities such as the buying of illegal drugs in large amounts and re-selling in smaller quantities at a profit of $50 \%$ (D22); gambling on street corners (D14); and, in the words of D17: "Sometimes you may think of stealing to get food so that the child may sleep having eaten. It is only after stealing that you realise what you did was wrong."

The daily struggle for survival without a secure income affects them individually, as well as their relations with others. As was found by Dawson (2014), Fowler and Etchegary (2008), Mckenzie (2013), Nayak (2006), and Sherman (2013), the pain is not just physical but also psychological. Additionally, it affects them in their roles as parent and as a community member (as they are seen as not contributing economically and perhaps as a liability). The latter can cause them to withdraw from social interaction, which in turn can diminish ties to employed people who can provide potential links to job opportunities (see Sherman, 2013; Zeng, 2012). Efforts of the unemployed to find alternative ways to secure an income were also reported in previous studies. Dawson (2014), Giazitzoglu (2014), Mckenzie (2013), Nayak (2006), and Patrick (2014) illustrated how 'working the welfare system', and engaging in political rioting in return for benefits, as well as crime and drug-dealing, were applied to sustain survival efforts.

\section{Theme 2: Hope and optimism}

Participants shared a general perception that unemployment is not the result of a person's deficiencies or wants. One interviewee summarised this as follows: "... when you get a job it is not about anything else than that you have been blessed. It was your time to find that job at that time" (D23). It seems as if their unemployment situation was something which they cannot control. Four of the interviewees found relief in the belief that God would provide a job in His time; one should just continue believing and do the best in looking for a job (D17, D18, D20, \& D21). D1 and D14 strongly believed that obedience to their ancestors would improve their situation and that their ancestors' presence and influence would bring change when the time was right. Although they would "wait patiently" for external forces or changes in the larger socio-economic and political environment, they did not want to be perceived by others or by God and/or the ancestors as not doing their part. They would wait in an "active mode" and demonstrate that they are neither lazy nor idle by. This "active mode" includes, for instance, going to church, looking for a job, or honouring their ancestors.

Evidently, this is a type of transactional attitude built on the assumption that "when I do right, I can expect good things to happen." Moreover, the respondents believed that leaving their home and actively engaging with life would increase their chances of 'bumping' into a lucky break and finding a job or apprenticeship/learnership, also called "luck to change" (D18). All participants looked forward to eventually gaining formal employment. They had high hopes that their precarious situation would change for the better (D1, D2, D14, D16, D19, D20, D22, \& D23). A "good" job for the respondents meant a permanent 
position at a company or government institution under a fixed contract that included a good salary as well as health insurance, housing, a study bursary scheme, with rights to unemployment benefits (D1, D2, D16, D17, D18, \& D22) and that made possible a comfortable lifestyle (D2, D16, \& D19). Participants felt 'proudness' at their ability to endure, to learn from their struggles, and to achieve a level of success in other areas of their life tasks such as parenting (D1, D2, D16, D18, D19, \& D23).

In contrast with what was found in most other qualitative unemployment research studies, the findings of the current study found hope and optimism among unemployed people in these two townships. A case in point are the qualitative studies on unemployment done in North America, Canada, UK, and China which did not report the existence of hope or optimism exhibited by any of their unemployed participants (Fowler \& Etchegary, 2008; Giazitzoglu, 2014; Mckenzie, 2013; Nayak, 2006; Patrick, 2014; Sherman, 2013; Zeng, 2012). It might be postulated that this might be something unique about the unemployed individuals in the Southern African countries. The South African studies of Dawson (2014) and that of Nell, De Crom, Coetzee, and Van Eeden (2015), and Namibian study of Plattner and Gonzo (2010) accord with this study results which found that unemployed people, although unhappy and impatient with their precarious situation, still foster hope and undertake action plans to meet their aspirations for a better future.

\section{Theme 3: Living in a township community}

Participants spoke about the poor labour market conditions in their community and said that the lack of basic community resources or 'ubuntu' (the general meaning of ' $u$ buntu' is compassion and humanity) harmed people's sense of belonging. They viewed their township environment as a filthy, painful, sad, and forgotten place with dilapidated infrastructure and resources (D19, D20, \& D21). It was seen as offering virtually no job opportunities and being far removed from economic hubs, which in turn makes looking for a job tough (D1, D14, D16, D17, \& D18).

Moreover, they said that the township lacked leaders, mentors, and role models since most successful, skilled, and well-connected people had apparently left the township (D1, D14, D16, D20, D21, \& D22). Unemployed township people often fall victim to hoaxes and misunderstandings when it comes to job opportunities. This is because they lack discriminating abilities to recognise job opportunities offered by fraudulent agencies, since they lack correct information and proper guidance (D1, D14, \& D22). This leaderlessness of a community lacking the resources and opportunities of a broader community was also described by Fowler and Etchegary (2008) in their research on a high crisis community.

High unemployment diminished people's 'ubuntu' or community spirit due to mistrust, feelings of betrayal, and the deterioration of social cohesion (D14, D15, D19, D21, \& D22). Some community members begrudged the financial success of those who had found employment, success, and prosperity (D16, D22, \& D23) and were suspicious of the legitimacy of their financial success
(D2, D14, D16, D20, \& D21). They asked such questions as "How?"; "Why didn't they share the opportunity?"; and "Was the job obtained through straightforward and legitimate means?" (D14, D16, \& D20). Notwithstanding the fact that most of the inhabitants in this high crisis community suffered unemployment; financial independence and to be affluent seem to be a crucial measure of individual worth. However, although many of the informants said 'ubuntu' did not exist anymore (D1, D15, D17, D19, \& D23), two of the interviewees felt that 'ubuntu' was alive and well in their corner of the township as well as amongst their family members (D1 \& D16).

Most of the interviewees viewed both the larger township environment and their township community as negative, unsupportive, and as adding to their negative experience of being unemployed. The terms used to refer to the unemployed (for instance "cheese-boy", "loafer", "mama's baby", and "hustler" for an adult man who is incapable of financially supporting a family (D14, D15, D16; D20, \& D22)) were anti-ubuntu. D20 similarly said: "We are always concerned about what people say about us."

Negative experiences of their community, as well as perceiving it as being in a crisis because of limited resources and a lack of coherence was, also reported by unemployed participants in the UK and the US (Giazitzoglu, 2014; Patrick, 2014; Sherman, 2013). Some of the participants aspired to leave the township as soon as they could afford life outside it. Dawson (2014) showed that unemployed people would not just accept any job. Moreover, unemployed persons in the township are forced to reckon with the social reality that employed people do not socialise with the unemployed individuals. However, contrary to what was found in previous studies (Mckenzie, 2013; Nayak, 2006; Strier, 2014; Sung-Chan \& Yuen-Tsang, 2008; Zeng, 2012), most of the unemployed interviewees did not share experiences of an 'own' group that might buffer them from unsupportive 'others' in the larger community or society. According to Mackenzie (2013), people are valued based on their monetary value or what they own. This increases the stress on the unemployed individual, who has nothing and thus may risk being valued as 'nothing'. The residents' feelings of powerlessness seem to cause them to turn against each other and not to help one another. This experience of a resource-deprived community was reported in studies of high crisis communities (e.g. Fowler \& Etchegary 2008; Mckenzie, 2013). The eroding of the 'ubuntu' characteristic of African communities matches the results of Plattner and Gonzo (2010).

\section{Theme 4: Disconnected from political and economic forces}

Informants said their unemployment sprang from the government's economic reform failures (D2, D15, D18, D19, D20, D21, \& D23). According to the interviewees, unemployment was the result of failed promises from government to redress the unfairness of the oppression and past discriminations. According to D20, "The [government] always lies to us; making empty promises ... we need jobs." 
According to the participants, nepotism, favouritism, and other forms of corruption by government officials caused unemployment (D14, D15, D17, D20, D21, \& D22). They also felt deprived of a fair chance to compete in the job market. The interviewees said it was even more challenging to find a job against this background of nepotism, cronyism, favouritism, and corruption in job placements because they were not part of a connected network (D2, D18, D20, \& D21). Only interviewees D17 and D23 were slightly less critical of the government and pointed out that some programmes (for instance, those focused on getting more women into senior positions) did seem to be bearing fruit. Furthermore, both were sceptical that having a membership card of the African National Congress (the country's ruling political party) could secure someone a job. Many of the respondents very clearly felt abandoned and betrayed by their political leaders, and society at large. Participants described the president of the country as a 'father' who had forgotten his 'children' out in the cold and had left them behind without care (D2, D4, D19, \& D21).

Unemployed people's disillusionment about being unemployed by the formal sector was also reported in previous studies (e.g. Aldrich \& Dickie, 2012; Fowler \& Etchegary, 2008; Mackenzie, 2013; Sherman, 2013). These researchers found that the unemployed reported being socially marginalised and different from 'normal' people. The lack of caring and support from the "outside" represented by the national state agencies detracts from these individuals' well-being. Nell and colleagues (2015) also reported that the marginalised communities are "last in the row" (p. 178) when it comes to being assisted by the government. The lack of financial support during times of long-term unemployment, as well as imperfect wage policies by the South African government, were identified as a possible cause for increased negative experiences of unemployment in the study by Giep, Rothmann, Vleugels and De Witte (2012).

\section{Limitations of the study}

This study had various limitations. The study was exploratory and conducted in only two communities with the aim of gaining an initial understanding of the experience of unemployment. Many aspects of context, such as the respondents' families and the perception of the broader society, were not addressed in the interview questions. Further research is necessary to more thoroughly explore the different aspects of context. A second follow-up interview with the interviewees would also have contributed to a deeper understanding of certain aspects, such as the impact of negative self-stereotyping on the expectation of finding a job. Future research should focus on how best to empower unemployed individuals within support groups to build healthy and supportive environments for all.

\section{Conclusion}

Black community residents considered lack of employment by the formal sector to have negative individual and social status effects. At the individual level, the salient effects were a depressed feeling of being abandoned and neglected by the bigger society and political leaders. They experience frustration flowing from the fact that their need to be occupied by sensible and valuable contributions in society are not being met because of their unemployment situation. At the social status level, being unemployed came with stigmatisation, labelling, and marginalisation. Functional ties with an employed network also eroded their chances of receiving information from the corporate companies or state-owned enterprises. Many of these individuals exhibited resilient living and actively engaged with the informal employment sector. Nonetheless, they wished for employment in the formal sector which they associated with.

\section{Acknowledgements}

We would like to thank Dr Kerrin Myres, Richard Douglas, and Dr Susanne Friese for their invaluable advice and comments on the analysis process of this research. We would also like to thank the co-interviewers for their continued support and our interviewees for trusting us and sharing their stories with us. This work was financially supported by the Vlaamse Inter Universitaire Raad (VLIR).

\section{References}

Aldrich, R. M., \& Dickie, V. A. (2013). "It's hard to plan your day when you have no money": Discouraged workers' occupational possibilities and the need to reconceptualize routine. Work (Reading, Mass.), 45(1), 5-15. PMID:23531565

Altbeker, A., \& Bernstein, A. (2017, August). No country for young people: The crisis of youth unemployment and what to do about it. Retrieved from The Centre for Development and Enterprise (CDE) website: http://www.cde.org.za/ unemployment/wp-content/uploads/2015/12/CDE-EUpublication-No-country-for-young-people.pdf

Burger, R., Van der Berg, S., Van der Walt, S., \& Yu, D. (2017). The long walk: Considering the enduring spatial and racial dimensions of deprivation two decades after the fall of apartheid. Social Indicators Research, 130(1), 1101-1123. doi: 10.1007/s11205-016-1237-1

Creswell, J. W., \& Poth, C. N. (2017). Qualitative inquiry \& research design: Choosing among five approaches. London: Sage.

Dawson, H. (2014). Youth politics: Waiting and envy in a South African informal settlement. Journal of Southern African Studies, 40(4), 861-882. https://doi.org/10.1080/03057070. 2014.932981

De Witte, H., Rothmann, S., \& Jackson, L. T. B. (2012). On the psychological consequences of unemployment in South Africa: Experiences, coping and well-being of unemployed people. SA Journal of Economic and Management Sciences, 15(3), 235-252.

Flyvbjerg, B. (2010). Making social science matter: Why social inquiry fails and how it can succeed again. New York, NY: Cambridge University Press.

Fourie, F. C. V. N. (2011, June). The South African unemployment debate: Three worlds, three discourses? Department of Economics, University of the Free State SALDRU Working Paper, Number 63, University of Cape Town, Cape Town.

Fourie, F. C. V. N. (2012, September). Unemployment: state of knowledge, gaps and research priorities for an integrated approach. Paper presented at the Toward Carnegie III Conference, Cape Town.

Fowler, K., \& Etchegary, H. (2008). Economic crisis and social capital: The story of two rural fishing communities. Journal of Occupational and Organizational Psychology, 81(2), 319-341. https://doi.org/10.1348/096317907X226972 
Friese, S. (2014). Qualitative data analysis with ATLAS.ti (2nd ed.). London: Sage.

Giazitzoglu, A. G. (2014). Learning not to labour: A micro analysis of consensual male unemployment. The International Journal of Sociology and Social Policy, 34(5/6), 334-348. https://doi.org/10.1108/IJSSP-07-2013-0083

Giep, Y., Rothmann, S., Vleugels, W., \& De Witte, H. (2012). Psychological dimensions of unemployment: A gender comparison between Belgian and South African unemployed. Journal of Psychology in Africa, 22(3), 303-313.

Kumar, R. (2014). Research methodology (4th ed.). London: Sage.

Leibbrandt, M., Finn, A., \& Woolard, I. (2012). Describing and decomposing post-apartheid income inequality in South Africa. Development Southern Africa, 29(1), 19-34. https:// doi.org/10.1080/0376835X.2012.645639

Lloyd, N., \& Leibbrandt, M. (2013). How do the non-searching unemployed feel about their situation? On the definition of unemployment. Emergence, 3(N3x), 1-7. Retrieved from http://www.econ $3 \times 3$.org/article/ how-do-non-searching-unemployed

Lloyd, N., \& Leibbrandt, M. (2014). New evidence on subjective well-being and the definition of unemployment in South Africa. Development Southern Africa, 31(1), 85-105. https:// doi.org/10.1080/0376835X.2013.864513

Mahajan, S. (2014, August). Economics of South African townships: Special focus on Diepsloot. World Bank Studies. Washington, DC: World Bank. https://doi. org/10.1596/978-1-4648-0301-7

Mckenzie, L. (2013). Fox-trotting the riot: Slow rioting in Britain's inner city. Sociological Research Online, 18(4), 1-10. https://doi.org/10.5153/sro.3155

Nayak, A. (2006). Displaced masculinities: Chavs, youth and class in the post-industrial city. Sociology, 40(5), 813-831. https://doi.org/10.1177/0038038506067508

Nell, W., De Crom, E., Coetzee, H., \& Van Eeden, E. (2015). The psychosocial well-being of a "forgotten" South African community: The case of Ndumo, KwaZuluNatal. Journal of Psychology in Africa, 25(3), 171-181.

Patrick, R. (2014). Working on welfare: Findings from a qualitative longitudinal study into the lived experiences of welfare reform in the UK. Journal of Social Policy, 43(4), 705-725. https://doi.org/10.1017/S0047279414000294

Plattner, I. E., \& Gonzo, W. (2010). Social support, self-image, and future outlook among poverty-stricken unemployed men in Namibia: A phenomenological study. Journal of Psychology in Africa, 20(2), 171-177.
Sage, D. (2017). Reversing the negative experience of unemployment: A mediating role for social policies? Social Policy \& Administration, 0(0). doi:https://doi.org/10.1111/ spol.12333.

Seekings, J. (2003, March). Do South Africa's unemployed constitute an underclass? CSSR Working Paper No. 32. Published by the Centre for Social Science Research University of Cape Town, Cape Town, South Africa.

Sherman, J. (2013). Surviving the Great Recession: Growing need and the stigmatized safety net. Social Problems, 60(4), 409-432. https://doi.org/10.1525/sp.2013.60.4.409

Statistics South Africa. (2017, October). Quarterly Labour Force Survey: Quarter 3 (July to September). Retrieved October 31 2017 from http://www.statssa.gov.za/?p=10658

Statistics South Africa. (2017, August). Poverty Trends in South Africa: An examination of absolute poverty between 2006 \& 2015. Retrieved October 312017 from http://www.statssa. gov.za/?p=10341

Statistics South Africa. (2014, August 14). Informal business a means of survival. Retrieved March 42018 from http://www. statssa.gov.za/?p=3009

Statistics South Africa. (2014, August 14). Survey of employers and the self-employed. Retrieved March 42018 from http:// www.statssa.gov.za/?p=3016

Strier, R. (2014). Unemployment and fatherhood: Gender, culture and national context. Gender, Work and Organization, 21(5), 395-410. https://doi.org/10.1111/gwao.12044

Sung-Chan, P., \& Yuen-Tsang, A. (2008). Our journey nurturing the voices of unemployed women in China through collaborative-action research. Qualitative Social Work: Research and Practice, 7(1), 61-80. https://doi. org/10.1177/1473325007086416

Tracy, S. J. (2013). Qualitative research methods: Collecting evidence, crafting analysis, communicating impact. West Sussex: Wiley-Blackwell.

Yu, D. (2012). Defining and measuring informal employment in South Africa. Development Southern Africa, 29(1), 157-175. https://doi.org/10.1080/0376835X.2012.645649

Zeng, Q. (2012). Youth unemployment and the risk of social relationship exclusion: A qualitative study in a Chinese context. International Journal of Adolescence and Youth, 17(2-3), 85-94. https://doi.org/10.1080/02673843.2012.65 6196 